\title{
Seasonal Photoacclimation and Vulnerability Patterns in the Brown Macroalga Lessonia spicata (Ochrophyta)
}

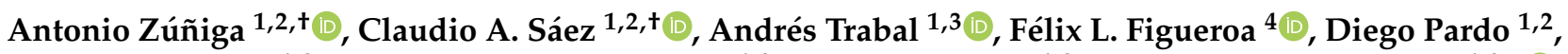 \\ Camilo Navarrete ${ }^{1,2}$, Fernanda Rodríguez-Rojas ${ }^{1,2}$, Fabiola Moenne ${ }^{1,2}$ and Paula S. M. Celis-Plá ${ }^{1,2, *(1)}$ \\ 1 Centre of Advanced Studies, Laboratory of Aquatic Environmental Research (LACER), Playa Ancha \\ University, Calle Traslaviña 450, 2581782 Viña del Mar, Chile; antonio.zuniga@upla.cl (A.Z.); \\ claudio.saez@upla.cl (C.A.S.); andres.trabal@gmail.com (A.T.); diego.pardo@upla.cl (D.P.); \\ camilo.navalb@gmail.com (C.N.); fernanda.rodriguez@upla.cl (F.R.-R.); fabiola.moenne@upla.cl (F.M.) \\ 2 HUB-AMBIENTAL UPLA, Playa Ancha University, 2340000 Valparaíso, Chile \\ 3 Escuela de Ciencias Agrarias y Veterinarias, Universidad de Viña del Mar, 2580022 Viña del Mar, Chile \\ 4 Ecology Department, Faculty of Sciences, Institute of Blue Biotechnology and Development (IBYDA), \\ Malaga University, Campus Universitario de Teatinos s/n, E-29071 Malaga, Spain; felix_lopez@uma.es \\ * Correspondence: paulacelispla@upla.cl \\ $\dagger$ These authors contributed equally to the investigation.
}

Citation: Zúñiga, A.; Sáez, C.A.; Trabal, A.; Figueroa, F.L.; Pardo, D.; Navarrete, C.; Rodríguez-Rojas, F.; Moenne, F.; Celis-Plá, P.S.M. Seasonal Photoacclimation and Vulnerability Patterns in the Brown Macroalga Lessonia spicata (Ochrophyta). Water 2021, 13, 6. https://dx.doi.org/ $10.3390 /$ w13010006

Received: 31 October 2020

Accepted: 18 December 2020

Published: 23 December 2020

Publisher's Note: MDPI stays neutral with regard to jurisdictional claims in published maps and institutional affiliations.

Copyright: ( $) 2020$ by the authors. Licensee MDPI, Basel, Switzerland. This article is an open access article distributed under the terms and conditions of the Creative Commons Attribution (CC BY) license (https://creativecommons.org/ licenses/by/4.0/).

\begin{abstract}
Fluctuations in solar radiation are one of the key factors affecting productivity and survival in habitat forming coastal macroalgae, in this regard, photoacclimation has a direct impact on the vulnerability and the capacity of seaweed to withstand, for instance, radiation excess. Here, we study ecophysiological responses through photosynthetic activity measurements under time-dependent (one year) fluctuations in solar radiation in the brown macroalga L. spicata. The responses presented seasonal patterns, with an increase in photosynthetic capacity during summer, expressed in greater maximal electron transport rate $\left(\mathrm{ETR}_{\max }\right)$ and diminished thermal dissipation $\left(\mathrm{NPQ}_{\max }\right)$. Moreover, we studied photoprotective compounds (phenolic compounds) and total antioxidant capacity, which demonstrated an increase during periods of high solar radiation. In addition, content of photosynthetic pigment ( $\mathrm{Chl} a, \mathrm{Chl} c$ and Carotenoids) increased under greater solar irradiance. The L. spicata can accumulate as reservoir photoprotective and antioxidant substances to withstand periods of high solar irradiance. All ecophysiological and biochemical responses in L. spicata indicate high photoacclimation and low vulnerability in the species, especially during with greater levels of solar irradiance.
\end{abstract}

Keywords: Lessonia spicata; brown macroalgae; photoprotective compounds; antioxidant capacity

\section{Introduction}

In the last century, according to the Intergovernmental Panel on Climate Change [1] each decade has been successively warmer than the previous one, illustrating one of the main consequences of global climate change. In addition to greater atmospheric $\mathrm{CO}_{2}$, there have been increasing patterns in the surface solar radiation resulting from the destruction of the ozone layer by chlorofluorocarbons (CFCs) and other substances that deplete atmospheric ozone [2]. In this context, the study of the photosynthetically active radiation (PAR, $\lambda=400-700 \mathrm{~nm}$ ) and ultraviolet radiation (UVB, $\lambda=280-315 \mathrm{~nm}$ and UVA, $\lambda=315-400 \mathrm{~nm}$ ) are important factors influencing primary production (photosynthetic organisms) and the ecological balance of marine organisms [3].

In central Chile, solar radiation varies throughout the year, with levels increasing from winter to summer [4]. Although there is some data on radiation levels in the area, there is no information on how photoautotrophic organisms respond upon increases and the effects on ecological balance, and how they will be affected in the medium to long term [5]. Radiation in central Chile can reach levels of up to $680.9 \mathrm{MJm}^{-2}$ in summer [5]. Moreover, 
in the coastal waters off Central Chile, the coastal upwelling occurs in seasonal cycles and the strong southerly upwelling favors winds prevailing during spring-summer [6]. Therefore, Central Chile can be a helpful natural laboratory to carry out cutting-edge investigations on photobiology, photo-accumulation, and radiation tolerance in photosynthetic organisms. Oscillations in solar radiation can affect responses in photoacclimation or in the vulnerability of the sessile species as macroalgae $[7,8]$.

It is known that the excess of radiation can disrupt the electron transport, causing an overproduction of reactive oxygen species (ROS), and in some cases, the presence of the solar radiation in low tidal zones, can induce oxidative stress and, in extreme cases, damage and cellular death [8-10]. Thus, it has been observed that one of the first metabolic processes after exposure to excess solar radiation in brown macroalgae corresponds to an impact on photosynthetic processes and on the induction in the biosynthesis of photoprotective and antioxidant compounds [11]. In this regard, macroalgae are considered vulnerable with respect to high ultraviolet radiation as it induces an imbalance between photodamage, photoprotection, and photo-repair mechanisms $[9,11]$. The concept of the vulnerability in macroalgae is associated with their photoacclimation and photo-accumulation abilities, defined as the concentration of photoprotective compounds synthesized under higher irradiance, which usually occurs during periods of low tide [7,12].

Stress caused by high solar radiation in brown macroalgae has been observed to enhance the production of different photoprotective compounds as polyphenols (also called phenolic compounds or phlorotannins) and carotenoids [5]. Polyphenols and carotenoids play an important role in dissipating energy and as antioxidants. The antioxidant properties of polyphenols are related to phenolic rings, which serve as electron donors for ROS as superoxide anions and hydroxyl radical [13]. Interestingly, the polyphenols in brown macroalgae have been found to have even stronger antioxidant capacities than in terrestrial plants [11,14]. In this context, it is well known that the use of photoprotective compounds and antioxidants extracted from brown seaweeds can be used for different biotechnological purposes, considering the pharmaceutical, cosmeceutical and food industries [15]; thus, it is certainly relevant to increase our knowledge on different macroalgae species to address basic responses and biotechnological potential.

Macroalgae have proven to be good biomonitoring organisms and represent ecosystem status, especially due to their sessile nature, widespread distribution, and responses to environmental disturbances [16]. However, despite the latter, the focus of most studies in Chile have been to develop evaluations associated with contamination $[5,10,17,18]$, but there is scarce information on their physiological and biochemical responses with respect to stress, eventually caused by naturally fluctuating environmental conditions. Hence, in this investigation we studied the physiological and biochemical responses of Lessonia spicata (Surh) Santelices (Laminariales, Phaeophyceae, Ochrophyta), highly abundant brown macroalgae in the western Pacific Coast, and greatly relevant as key habitat-forming species in intertidal coastal ecosystems $[5,19]$. Therefore, we studied L. spicata vulnerability and photoacclimation, as well as the photosynthetic production, accumulation, and induction of photoprotection compounds and antioxidant capacity throughout seasonal fluctuations in solar irradiance.

\section{Material and Methods}

\subsection{Species and Sampling Location}

Nine L. spicata thalli were collected at least $2 \mathrm{~m}$ distance among the thalli at $0.1-0.4 \mathrm{~m}$ above Chart Datum at 10:00 local Chilean time, on the 20th of each month from March 2019 to February 2020, throughout summer, autumn, winter, and spring. The samples were collected from the rocky shore at Cochoa Beach, Viña del Mar, Chile (32 57'19.0" S, $\left.71^{\circ} 32^{\prime} 52.4^{\prime \prime} \mathrm{W}\right)$. For photosynthetic evaluations, live material was transported in cooler boxes. For biochemical assessments, $L$. spicata blades were immediately frozen in liquid nitrogen, transported to the laboratory, and stored at $-80^{\circ} \mathrm{C}$ for further analyses. 


\subsection{Abiotic Parameters}

The photosynthetically active radiation (PAR, $K=400-700 \mathrm{~nm}$ ), and ultraviolet A radiation (UVA, $K=320-400 \mathrm{~nm}$ ) were measured in the air and in the water, column using QSO-SUN 2.5V and USB-SU 100 cosine-corrected sensors (Apogee Instruments, Logan, UT, USA), respectively. Each PAR and UVA sensor was inside a polycarbonate box (Otter Box 3000) $[20,21]$. Water temperature was measured monthly with a waterproof temperature data logger (HOBO Pendant ${ }^{\circledR}$ Temperature, Onset Data Loggers, Bourne, MA, USA). Salinity, $\mathrm{pH}$, and conductivity were measured using a multiparameter water quality meter (HI 98194, Hanna Instruments, Woonsocket, RI, USA). In addition, PAR diffuse attenuation coefficient $\left(\mathrm{K}_{\mathrm{dPAR}}\right)$ for downward irradiance in the water column, was calculated measuring PAR radiation just below the water surface and every $0.5 \mathrm{~m}$ depth in the water column. The Beer-Lambert law was used to calculate the attenuation coefficients; the $\mathrm{k}$ values were expressed in $\mathrm{m}^{-1}$.

\subsection{Photosynthesis and Energy Dissipation Measurements}

In vivo chlorophyll $a$ fluorescence of Photosystem II was measured in blades using portable pulse amplitude modulated fluorometer (MINI-PAM II—Walz GmbH, Germany).

L. spicata basal fluorescence $\left(F_{t}\right)$ and maximal fluorescence $\left(F_{m^{\prime}}\right)$ were measured under light conditions to obtain the effective quantum yield $\left(\Delta F / F_{m^{\prime}}\right)$ being $\Delta F=F_{m^{\prime}}-F_{t} / F_{m^{\prime}}$. To determine maximal quantum yield $\left(F_{v} / F_{m}\right)$, algal thalli was incubated in a dark chamber with fresh seawater for 15 min before measuring rapid light curves to fully photo-reduce all reaction centers. $F_{v}$ is the variable fluorescence as the difference between $F_{m}$ and $F_{o}$, being $F_{m}$ the maximal fluorescence and $F_{o}$ the basal fluorescence of dark-adapted thalli.

The electron transport rate (ETR) was determined by exposing the tissue for $20 \mathrm{~s}$ to twelve irradiances of actinic light in the rapid light curve (RLC), E1 $=25, \mathrm{E} 2=45, \mathrm{E} 3=66$, $\mathrm{E} 4=90, \mathrm{E} 5=125, \mathrm{E} 6=190, \mathrm{E} 7=285, \mathrm{E} 8=420, \mathrm{E} 9=625, \mathrm{E} 10=845, \mathrm{E} 11=1150$ and $\mathrm{E} 12=1500 \mu \mathrm{mol}$ photons $\mathrm{m}^{-2} \mathrm{~s}^{-1}$, by using the following formula by [22]:

$$
\operatorname{ETR}\left(\mu \mathrm{mol} \text { electrons } \mathrm{m}^{-2} \mathrm{~s}^{-1}\right)=\Delta F / F_{m^{\prime}} \times E \times A \times F_{I I}
$$

where $\Delta F / F_{m^{\prime}}$ is the effective quantum yield, $E$ is the PAR on each pulse of light expressed in $\mu \mathrm{mol} \mathrm{m} \mathrm{m}^{-2} \mathrm{~s}^{-1}, A$ is the blade absorptance equivalent to the fraction of the incident irradiance that is absorbed by the algae [23], and $F_{I I}$ is the portion of chlorophyll a related to PSII (400-700 nm), being 0.8 in brown macroalgae [9].

The ETR parameters as maximum electron transport rate $\left(E_{T R} \max \right)$, and the initial slope of ETR versus irradiance function $\left(\alpha_{\mathrm{ETR}}\right)$ as index of photosynthetic efficiency, were calculated from the tangential model by [24]. Saturation irradiance (Ek $\left.k_{\mathrm{ETR}}\right)$ was calculated from the intercept of ETR $R_{\max }$ and $\alpha_{\mathrm{ETR}}$.

Non photochemical quenching (NPQ) was calculated as proposed by [25]:

$$
\mathrm{NPQ}=\mathrm{Y}(\mathrm{NPQ}) / \mathrm{Y}(\mathrm{NO})=\left(F_{m-} F_{m^{\prime}}\right) / F_{m^{\prime}}
$$

Finally, maximal non photochemical quenching $\left(\mathrm{NPQ}_{\max }\right)$, the initial slope of NPQ versus irradiance function $\left(\alpha_{\mathrm{NPQ}}\right)$ and the saturation of irradiance of the $\mathrm{EK}_{\mathrm{NPQ}}$, were obtained from the hyperbolic tangent fitting models, according to [26] of NPQ versus irradiance. The yield of losses, $\mathrm{Y}(\mathrm{NO})$ and $\mathrm{Y}(\mathrm{NPQ})$ are determined according to [27] and [28], where $\mathrm{Y}(\mathrm{NO})$ is the fraction of energy passively dissipated in form of heat and fluorescence, mainly due to closed PSII reaction centers. High values indicate inability to protect itself against photodamage by excess radiation.

$$
\mathrm{Y}(\mathrm{NO})=F_{t} / F_{m}
$$

$\mathrm{Y}(\mathrm{NPQ})$ is the fraction of energy dissipated in form of heat via regulated photoprotective NPQ mechanisms. 


$$
\mathrm{Y}(\mathrm{NPQ})=\left(F_{t} / F_{m^{\prime}}\right)-\mathrm{Y}(\mathrm{NO})
$$

\subsection{Biochemical Variables}

The pigments were extracted from $20 \mathrm{mg}$ of nitrogen-grounded fresh tissue with $1.5 \mathrm{~mL}$ of $90 \%$ acetone. Samples were incubated overnight at $4{ }^{\circ} \mathrm{C}$ in the darkness and then centrifuged at 16,200 $\mathrm{g}$ (NU-C200R, NuWind, Plymouth, MN, USA) for $10 \mathrm{~min}$ at $4{ }^{\circ} \mathrm{C}$. Finally, for chlorophyll a (Chla) and c (Chlc), the absorbance was determined at 510, 630, 664 , and $750 \mathrm{~nm}$, according to [29], and for the total carotenoids the absorbance at $480 \mathrm{~nm}$ as proposed by [30]. These analyses were conducted using a microplate spectrophotometer (SPECTROstar Nano, BMG Labtech, Offenburg, Germany). Pigment concentrations were expressed as $\mathrm{mg} \mathrm{g}^{-1}$ dry weight after determining the fresh to dry weight ratio ( 2.84 for L. spicata).

The polyphenols or phenolic compounds (PC) were measured using 0.25 grs of frozen fresh tissue and mixed with 2.5 milliliters $(\mathrm{mL})$ of $80 \%$ methanol in $15 \mathrm{~mL}$ conical tubes. Mixtures were incubated overnight at $4{ }^{\circ} \mathrm{C}$ in the darkness with vigorous agitation and then centrifuged at $2253 \mathrm{~g}$ for $30 \mathrm{~min}$ at $4{ }^{\circ} \mathrm{C}$. The supernatant was collected to measure PC content colorimetrically using Folin-Ciocalteu reagent [31] and phloroglucinol (1,3,5trihydroxybenzene, Sigma P-3502) as standard. Finally, the absorbance was determined at $760 \mathrm{~nm}$ with the microplate reader [7]. Phenolic concentration was expressed as $\mathrm{mg} \mathrm{g}^{-1}$ dry weight.

Antioxidant activity DPPH (2,2-diphenyl-1-picrylhydrazyil) assay (i.e., $\left.\mathrm{EC}_{50}\right)$ was estimated by reducing the stable free radical DPPH [32]. In this regard, the supernatant for PC can also be used for this analysis [7,12]. DPPH solution was prepared in $90 \%$ methanol in distilled water $\left(90 \mathrm{MeOH}: 10 \mathrm{H}_{2} \mathrm{O}\right)$ to a concentration of $1.27 \mathrm{mM}$. The reaction was complete after $30 \mathrm{~min}$ in a dark room at $20^{\circ} \mathrm{C}$, and the absorbance was read at $517 \mathrm{~nm}$ using the microplate reader. A calibration curve made with DPPH was used to calculate the remaining concentration of DPPH in the reaction mixture after incubation. Finally, Trolox (6-Hydroxy-2,5,7,8-tetramethylchromane-2-carboxylic acid) (0 to $50 \mu \mathrm{M})$ was applied as the reference antioxidant. The results obtained were expressed as $\mu \mathrm{mol}$ TEAC (Trolox equivalent antioxidant capacity) $\mathrm{g}^{-1} \mathrm{DW}$.

\subsection{Statistical Analysis}

The significant effects between physiological and biochemical variables were analyzed using ANOVA according to [33]. This test was performed for L. spicata including month (one-way) as a fixed factor with 12 levels (mean $\pm S E, n=9$ ); the probability applied in the statistical analysis was $p<0.05$. Homogeneity of variance was tested using Cochran tests and by visual inspection of the residuals. Student Newman-Keuls tests (SNK) were performed after significant ANOVA interactions. Homogeneity of variance and homoscedasticity were tested using Cochran's C-tests tests and by visual inspection of the residuals. All data conformed to homogeneity of variance. Analyses were performed by using SPSS v.21 (IBM, Endicott, New York, NY, USA). The general variation patterns between physiological and biochemical variables measured in L. spicata were explored using a multivariate approach. A principal coordinates analysis (PCO) was performed for this purpose based on Euclidean distance using PERMANOVA+ within PRIMER v.6 software package [34]. Each one of the variables was represented by an arrow in the ordination plot pointing to the samples displaying the highest amount of that compound. Pearson correlation coefficients were calculated and tested between all measured dependent variables using Sigma plot 12.0 (Systat software, Slough, Berkshire, UK).

\section{Results}

\subsection{Environmental Conditions}

The seawater temperature ranged from $12.25-15.21^{\circ} \mathrm{C}, \mathrm{pH}$ from $7.90-8.01$, salinity between 31.74 and 33.98 PSU (Table 1), with a peak average daily irradiance of ca. $9000 \mathrm{~kJ} \mathrm{~m}^{-2}$ 
for PAR, and $750 \mathrm{~kJ} \mathrm{~m}^{-2}$ for UVA in summer (Figure 1). The $\mathrm{K}_{\mathrm{dPAR}}$ in the coastal waters under different seasonal periods was $0.360 \mathrm{~m}^{-1}, 0.288 \mathrm{~m}^{-1}, 0.304 \mathrm{~m}^{-1}$ and $0.336 \mathrm{~m}^{-1}$, in autumn, winter, spring and summer time, respectively (Table 1, Figure 2).

Table 1. Abiotic parameters: Temperature $\left(\mathrm{T}^{\circ} \mathrm{C}\right), \mathrm{pH}$, salinity and PAR diffuse attenuation coefficients $\left(\mathrm{K}_{\mathrm{dPAR}}\right.$ express in $\mathrm{m}^{-1}$ ) measured in the water column in the Cochoa Beach (Reñaca-Chile), on a monthly basis from March 2019 to February 2020 along the autumn, winter, spring, and summer seasonal times.

\begin{tabular}{ccccc}
\hline & $\mathbf{T}^{\circ} \mathbf{C}$ & $\mathbf{p H}$ & Salinity & $\mathbf{K}_{\mathbf{d P A R}}$ \\
\hline Autumn & $13.57 \pm 1.22$ & $7.91 \pm 0.15$ & $33.91 \pm 1.13$ & 0.360 \\
Winter & $12.25 \pm 0.04$ & $7.90 \pm 0.09$ & $31.95 \pm 0.42$ & 0.288 \\
Spring & $13.53 \pm 0.70$ & $7.93 \pm 0.01$ & $31.74 \pm 0.25$ & 0.304 \\
Summer & $15.21 \pm 0.47$ & $8.01 \pm 0.04$ & $33.98 \pm 0.98$ & 0.336 \\
\hline
\end{tabular}
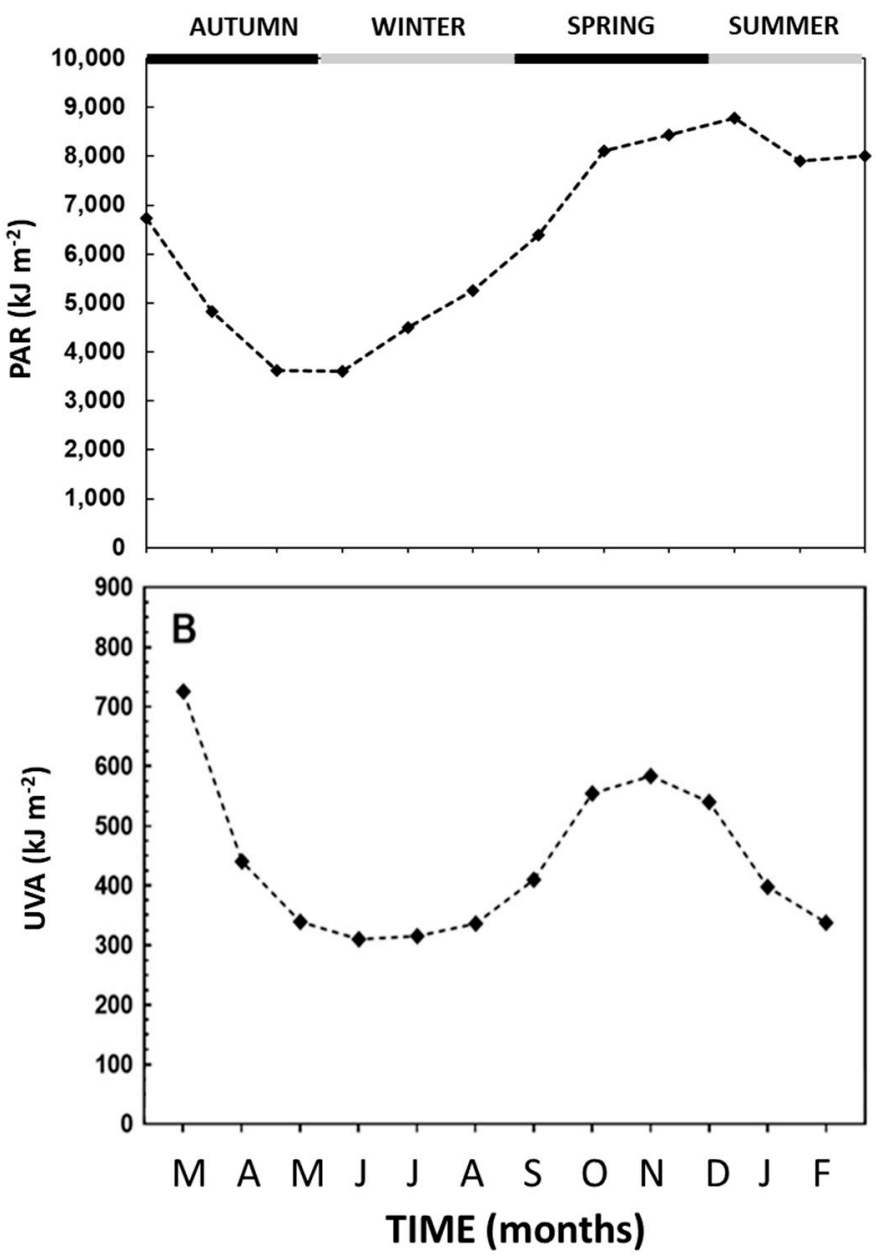

Figure 1. (Daily integrated irradiance (doses) of (A) Photosynthetically active radiation (PAR), expressed in $\mathrm{KJm}^{-2}$ and (B) Ultraviolet A (UVA) expressed in $\mathrm{KJm}^{-2}$, measured at the monitoring site in Central Chile from March 2019 to February 2020. 


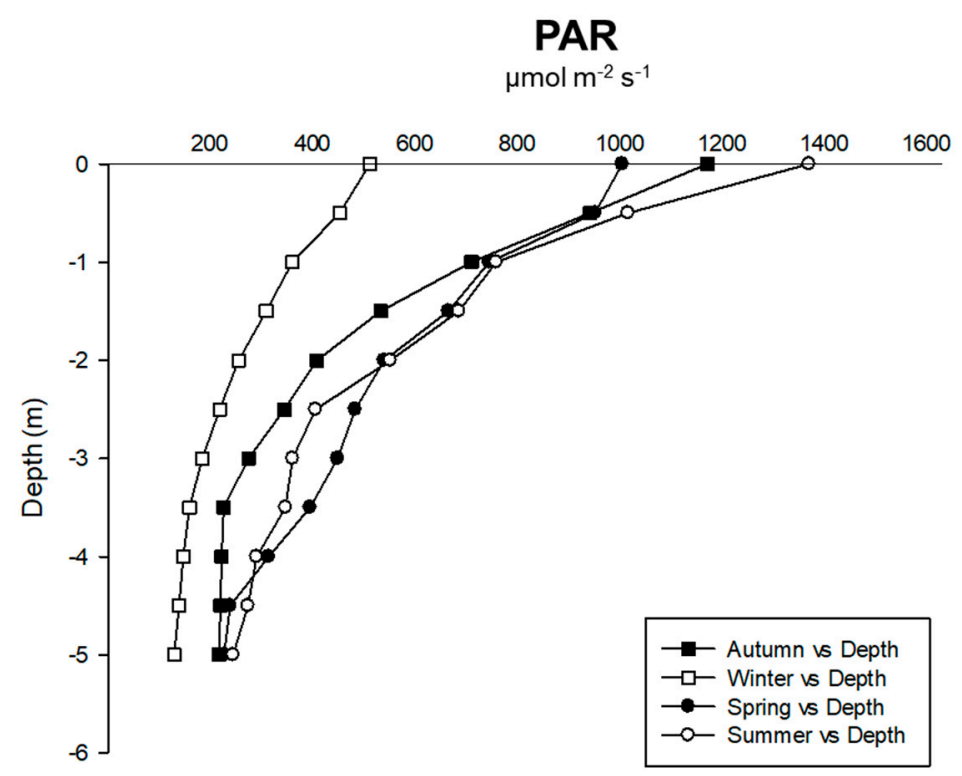

Figure 2. PAR diffuse attenuation coefficient $\left(\mathrm{K}_{\mathrm{dPAR}}\right)$ downwards the water column, measured at the monitoring site in Central Chile from March 2019 to February 2020.

\subsection{Physiological Responses and Biochemical Variables}

Principal coordinates analysis (PCO diagram; Figure 3) along the year, shows a positive correlation of the first axis (34.9\% of total variation) with $\mathrm{NPQ}_{\max }, \mathrm{Chl} a$ and Chlc, Car and Alfa $\mathrm{NPQ}_{\mathrm{NP}}$, being highest in the samples from springtime. On the other hand, $\mathrm{ETR}_{\max }, \mathrm{PC}, \mathrm{AA}$ and Ek $\mathrm{E}_{\mathrm{ETR}}$ were highest in the samples collected in summer and autumn, and they were positively correlated with this axis (23.5\% of total variation, Figure 3$)$. The small angles between the arrows are indicative of high positive correlation between the variables (Figure 3).

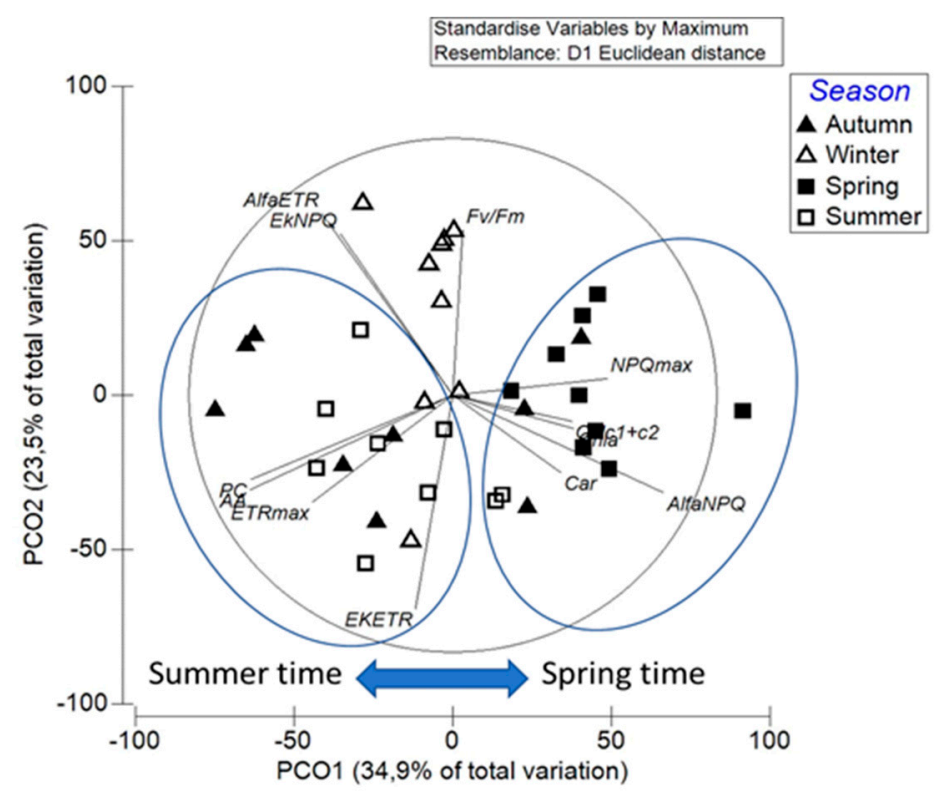

Figure 3. Principal coordinates diagram in relation to season (spring, summer, autumn, and winter). Vectors overlay (Spearman rank correlation) indicates the relationship between the PCO axes and the ecophysiological $\left(F_{v} / F_{m}, \mathrm{ETR}_{\max }, \mathrm{Alfa}_{\mathrm{ETR}}, \mathrm{Ek}_{\mathrm{ETR}}, \mathrm{a}_{\mathrm{NPQ}}, \mathrm{NPQ}_{\max }, \mathrm{Ek}_{\mathrm{NPQ}}\right)$, and biochemical (PC, AA, $\mathrm{Chl} a, \mathrm{Chl}_{c 1+c 2}$ and Car) variables throughout time.

ETR versus irradiance (rapid light curves) in the months reaching maximal (April) and minimal (July) values are presented in Figure 4A. In April, the maximal value of 
$88 \mu \mathrm{mol} \mathrm{m} \mathrm{m}^{-2} \mathrm{~s}^{-1}$ was reached, whereas in July only $30 \mu \mathrm{mol} \mathrm{m} \mathrm{m}^{-2} \mathrm{~s}^{-1}$ was reached (Figure 4A). The NPQ was lower in April and increased in the wintertime or July (Figure 4B). Yield II decreased with the irradiance, reaching the minimal values in April around 0.2, whereas the minimal values in July were around $0.1 \approx 0.05$ (Figure $4 \mathrm{C}, \mathrm{D}$ ). In the same context, yield loss as $\mathrm{Y}(\mathrm{NO})$ was the same trend in both months, with high values of 0.58 in July (Figure $4 \mathrm{C}, \mathrm{D})$. Finally, the maximal values of $\mathrm{Y}(\mathrm{NPQ})$ were 0.55 in July (Figure $4 \mathrm{C}$ ) and 0.7 in April (Figure 4D). At irradiances lower than $100 \mu \mathrm{mol}$ photons $\mathrm{m}^{-2} \mathrm{~s}^{-1}$, values of $\mathrm{Y}(\mathrm{NO})$ were higher than $\mathrm{Y}(\mathrm{NPQ})$, whereas at irradiances higher than $400 \mu \mathrm{mol}$ photons $\mathrm{m}^{-2} \mathrm{~s}^{-1}$ were the reverse.
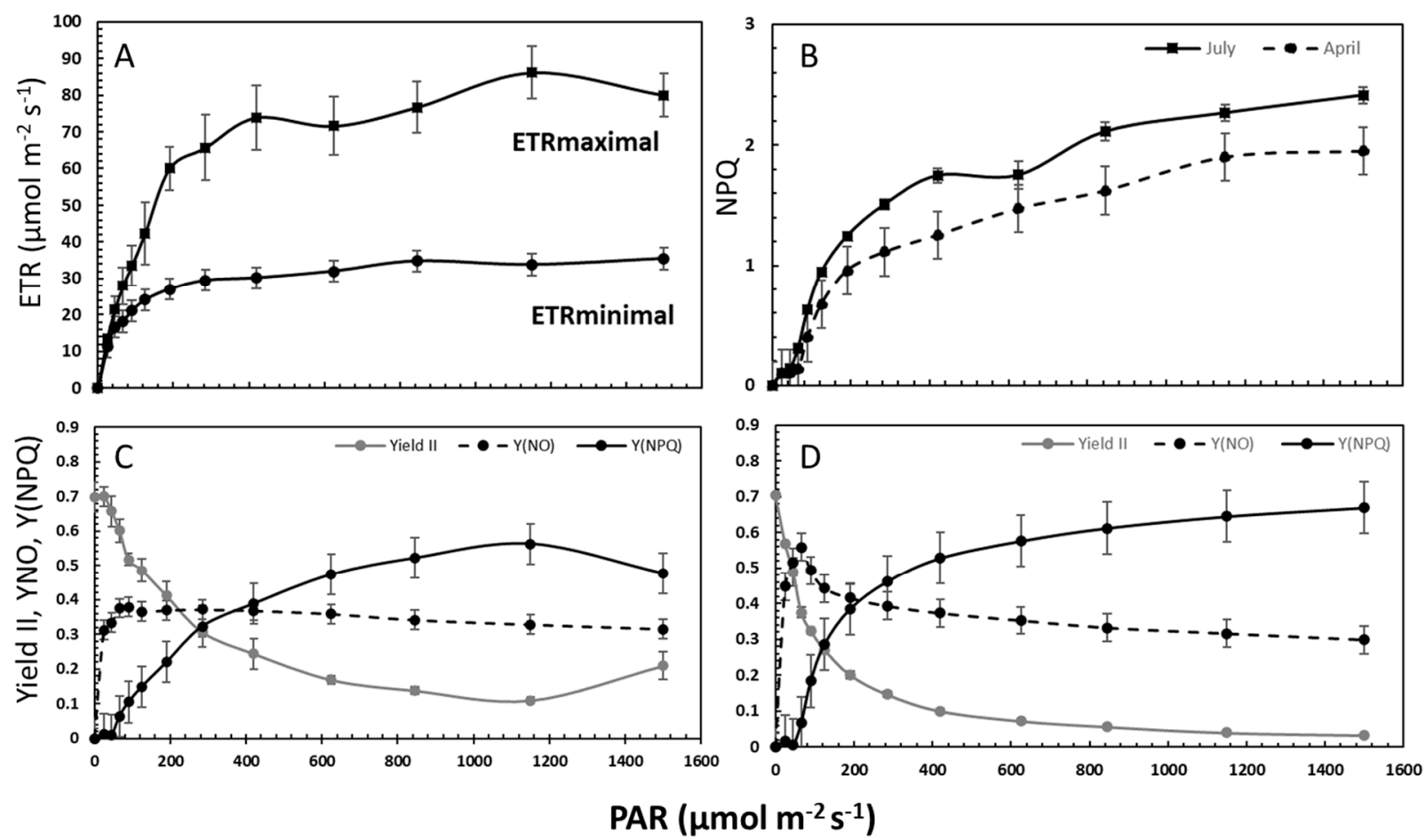

Figure 4. (A) Electron transport rate curve with maximal values in April and Electron transport rate (ETR) curve with minimal values in July along the seasonal time, (B) Non-Photochemical quenching (NPQ) curve vs irradiance with maximal values in July and NPQ curve with minimal values in April along the seasonal time, (C) Yield II, Y(NO) and Y(NPQ) curves in April with maximal values, and (D) Yield II, Y(NO) and Y(NPQ) curves in July with minimal values in L. spicata measured at Cochoa Beach, Viña del Mar, Chile, between autumn and summertime.

The $F_{v} / F_{m}$ varied significantly depending on time $(\mathrm{p}<0.05)$ (Figure $5 \mathrm{~A}$ and Table S1). $F_{v} / F_{m}$ increased in samples collected in wintertime. ETR max $_{\text {increased in summer and }}$ autumn (Figure 5B and Table S1). Also, $\alpha_{\text {ETR }}$ was significantly higher in winter, summer and autumn (Figure 6A and Table S1). The Ek $k_{E T R}$ increased significantly in summertime (Figure $6 \mathrm{~B}$ and Table $\mathrm{S} 1$ ). The $\mathrm{NPQ}_{\max }$ was significantly different throughout the year $(p<0.05)$ (Figure 7 and Table S1). The NPQ ${ }_{\max }$ increased under low temperature and low irradiance conditions in wintertime (Figure 7).

$\mathrm{Chl} a$ and Chlc contents were significantly different throughout the sampling period $(p<0.05)$ (Figure 8 and Table S2). The significant differences revealed clear differences along time, which were that $\mathrm{Chl} a$, Chlc and carotenoids were higher in springtime compared to the rest to the year (Figure 8). 

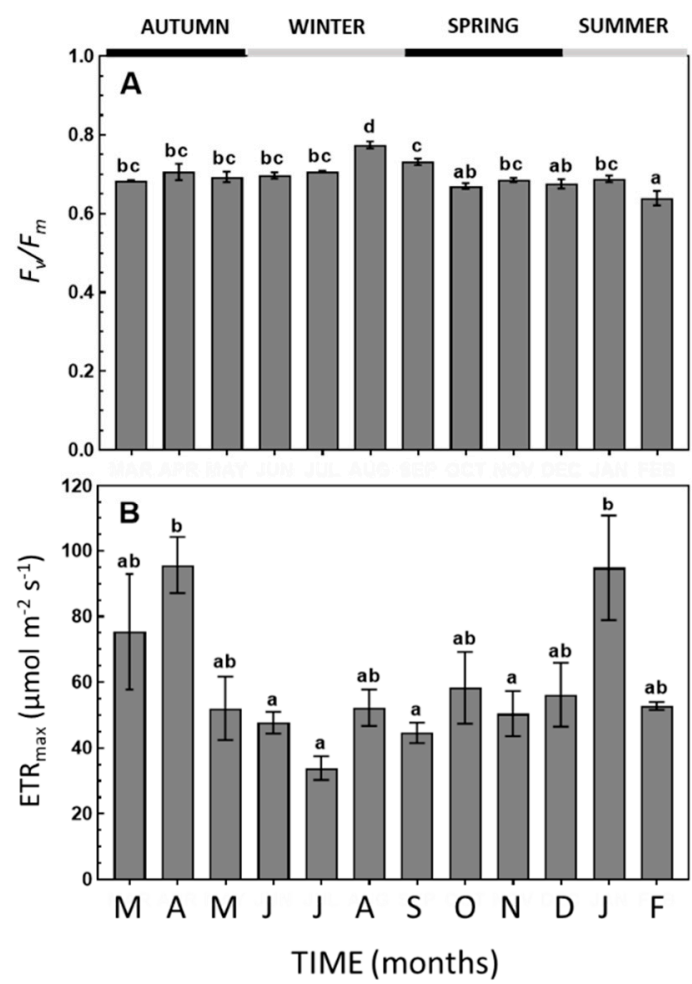

Figure 5. (A) Maximal quantum yield $\left(F_{v} / F_{m}\right)$, and (B) maximal electron transport rate $\left(\mathrm{ETR}_{\max }\right)$ in L. spicata measured at Cochoa Beach, Viña del Mar, Chile, between autumn and summertime. Letters indicate significant differences after the Student Newman Keuls (SNK) test $(p<0.05)$.

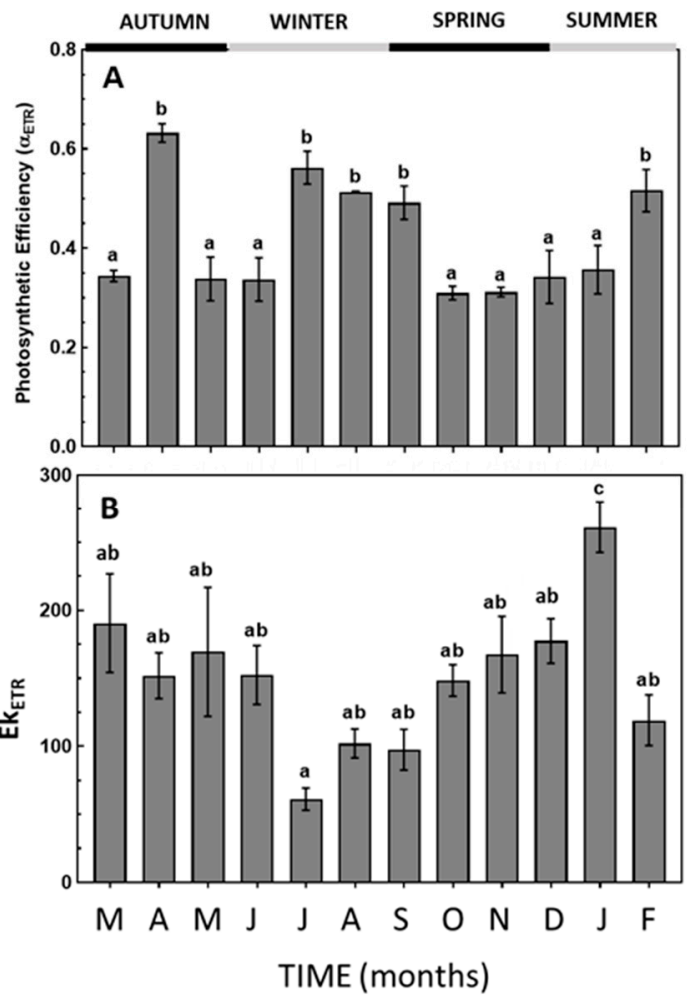

Figure 6. (A) Photosynthetic efficiency $\left(\alpha_{\mathrm{ETR}}\right)$, and (B) saturation of irradiance (Ek $\left.\mathrm{ETR}_{\mathrm{E}}\right)$ in L. spicata measured at Cochoa Beach, Viña del Mar, Chile, between autumn and summertime. Letters indicate significant differences after the SNK test $(p<0.05)$. 


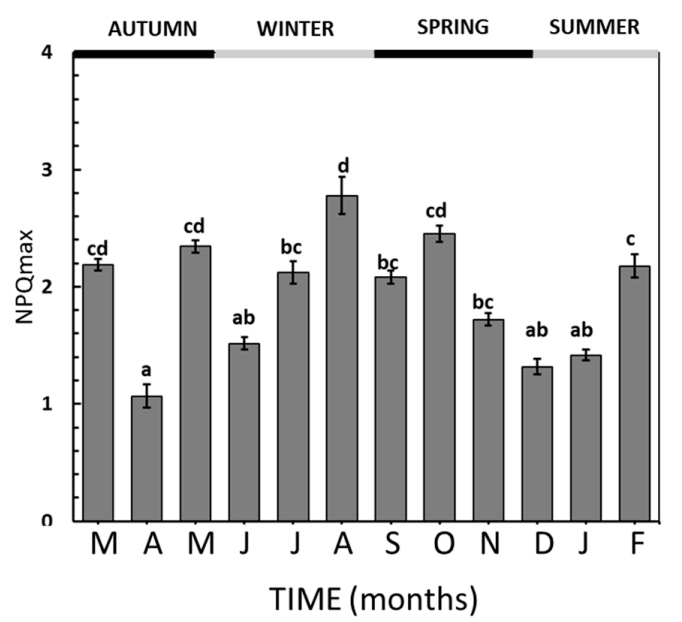

Figure 7. Maximal non-photochemical quenching $\left(\mathrm{NPQ}_{\max }\right)$ in L. spicata measured at Cochoa Beach, Viña del Mar, Chile, between autumn and summertime. Letters indicate significant differences after the SNK test $(p<0.05)$.

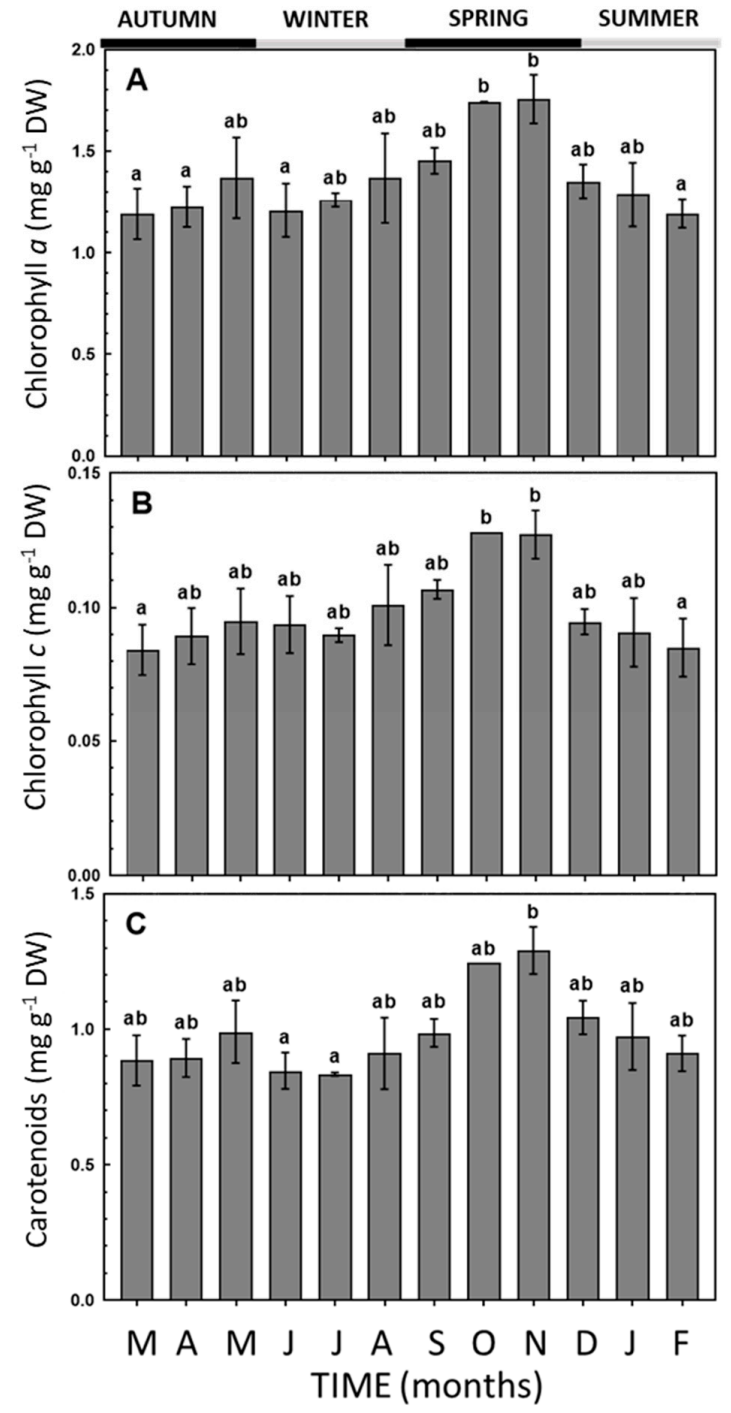

Figure 8. Photosynthetic pigments: (A) chlorophyll $a,(\mathbf{B})$ chlorophyll $c$, and (C) total carotenoids, quantified in L. spicata at Cochoa Beach, Viña del Mar, Chile, from autumn to summertime. Letters indicate significant differences after the SNK test $(p<0.05)$. 
The PC and AA presented significant differences throughout the year (Figure 9, Table S2). PC decreased in wintertime and increased in spring, presenting the highest values in summer (Figure 9A). Similar values presented the antioxidant capacity with the greatest levels in summertime (Figure 9B).
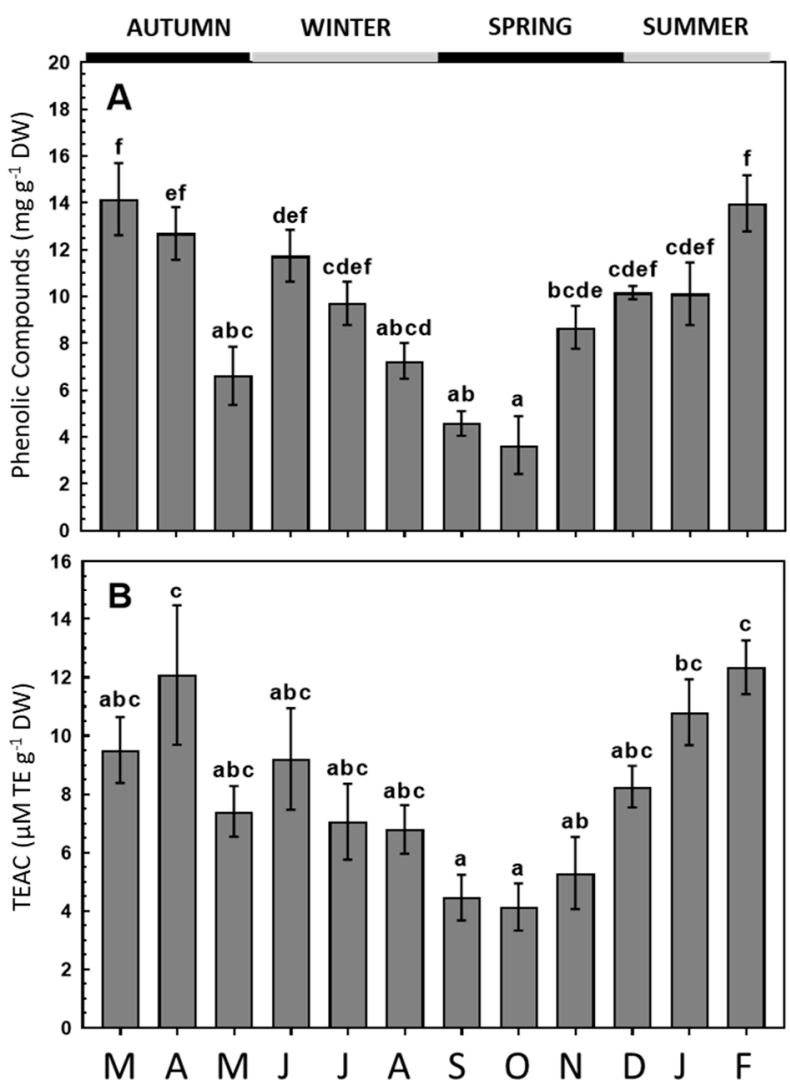

Figure 9. (A) Phenolic compounds content $\left(\mathrm{mg} \mathrm{g}^{-1} \mathrm{DW}\right)$, and (B) Trolox equivalent antioxidant capacity (DPPH method), quantified in L. spicata collected at Cochoa Beach, Viña del Mar, Chile, from autumn to summertime. Letters indicate significant differences after the SNK test $(p<0.05)$.

The Pearson correlation showed a positive correlation between PC and AA, throughout all seasons and months (Table S3). Furthermore, a positive correlation was found between $\alpha_{\mathrm{ETR}}, \mathrm{Ek}_{\mathrm{ETR}}, F_{v} / F_{m}$, and $\mathrm{ETR}_{\max }$, and between $\mathrm{ETR}_{\max }$ and antioxidant activity. Finally, $\mathrm{NPQ}_{\max }$, pigment content and photoprotective and antioxidant activity were positively correlated (Table S3).

\section{Discussion}

Photophysiological, biochemical and biological responses in habitat-forming species L. spicata presented seasonally dependent variation caused most likely due to fluctuations in solar radiation. We found that the maximum electron transport rate $\left(\mathrm{ETR}_{\max }\right)$, phenolic compounds, antioxidant activity, and saturation of irradiance in ETR $\left(\mathrm{E}_{\mathrm{kETR}}\right)$ increased in summer, whereas $\mathrm{NPQ}_{\max }, \mathrm{Chl} a, \mathrm{Chl} c$, and carotenoids increased in springtime (Figure 3). Our results suggest that the light stress in summertime can provoke photobiological and biochemical changes in L. spicata specimens, related to effective photoprotection of photosynthesis. The PAR diffuse attenuation coefficient $\left(\mathrm{K}_{\mathrm{dPAR}}\right)$ for downward irradiance in the water column, was $0.360 \mathrm{~m}^{-1}$ in autumn, $0.288 \mathrm{~m}^{-1}$ in winter, $0.304 \mathrm{~m}^{-1}$ in spring and $0.336 \mathrm{~m}^{-1}$ in summer, indicating less light penetration in the water column in the months with greater solar irradiance, such as a spring and summer; in contrast the highest light penetration occurred in wintertime. These variations can be explained by seasonal cycles with strong southerly upwelling due to increased winds prevailing during 
winter, and because nutrient content is limited in summer and can be also consumed by the phytoplankton e.g., [6].

In this study, the maximum quantum yield $\left(F_{v} / F_{m}\right)$ was higher at the end the winter, with values around 0.73 , and at the beginning of springtime; in this regard, $F_{v} / F_{m}$ is a useful parameter for a quick assessment of the photosynthetic conditions $[9,35]$ and is used as an indicator of photoinhibition on primary producers [36]. [5] show values of $F_{v} / F_{m}$ in L. spicata of 0.76 . Here, L. spicata specimens displayed a reduction around $15 \%$ in the $F_{v} / F_{m}$, in spring and summer, indicating that the alga suffered photoinhibition as it has been reported in other brown macroalgae species $[7,9,37]$. Photoinhibition of photosynthesis is usually linked to a reduced photosynthetic production or maximal electron transport rate $\left(\mathrm{ETR}_{\max }\right)[37,38]$, as well as related to limited availability of nutrients in seawater [39]. Here, the photosynthetic activity $\left(E_{T} R_{\max }\right)$, as index of productivity, which was higher in summertime, with almost $60-100 \mu \mathrm{mol} \mathrm{m}{ }^{-2} \mathrm{~s}^{-1}$. These results indicate that under higher irradiance of summer there may be decreased excitation transfer to the reaction centers due to photoinhibition. Similar results were found in Cystoseira tamariscifolia $[7,12]$ in spring and summer, with higher values in respect to the wintertime. The latter suggests that macroalgae may withstand radiation derived stress in springtime and decrease the vulnerability in wintertime. Indeed [21], showed similar results in Gelidium corneum plants, which were transplanted from areas with low to high irradiances (i.e., 3 to $5 \mathrm{~m}$ of depth in the water column).

In the same trend, the $\alpha_{\mathrm{ETR}}$ and $\mathrm{Ek}_{\mathrm{ETR}}$ increased in months with high solar irradiance, indicating a photoacclimation pattern typical of sun affinity algae [12]. In addition, the decrease in ETR $\mathrm{max}_{\max }$ observed in L. spicata throughout the year could be partially explained by increased energy demand from other photoprotection cellular processes [12,40,41]. In this context, it is known that photosynthetic activity can enhance the accumulation of PC in other brown macroalgae [42] as well as in the green macroalga Ulva rigida [43]. Indeed, the $\mathrm{NPQ}_{\max }$ dissipation in the form of heat, used as a photoprotection indicator, also associated to photoinhibition and the concentrations of the pigments, presented the highest trend of increase in springtime, this suggests, an increase of the nutrient fertilization, product by seasonal upwelling [6].

The energy dissipation pattern or yield loss in L. spicata at higher irradiances than $400 \mu \mathrm{mol}$ photons $\mathrm{m}^{-2} \mathrm{~s}^{-1}$ was produced under regulated photoprotective mechanisms, i.e., $\mathrm{Y}(\mathrm{NPQ})$ values were higher than $\mathrm{Y}(\mathrm{NO})$. In the summer period, the ETR presented the high values of the productivity index and the NPQ was lower for an increase in wintertime (July-August). The NPQ represents a loss of potential energy by the system probably involving several factors such as thermodynamic losses as waste heat and losses in the xanthophyll cycle of photosynthesis in some phototrophs [26]; thus, the contribution of non-photoregulated dissipation $\mathrm{Y}(\mathrm{NO})$ in the yield losses increased compared to April, but it remains lower than that of $Y(\mathrm{NPQ})$. Y(NPQ) was higher under nutrient-enriched periods compared to low conditions. The high values of $Y(N P Q)$ are indicative of a high photoprotective capacity, whereas high values of $\mathrm{Y}(\mathrm{NO})$ reflect the inability of a plant to protect itself against damage by excess illumination [44]. Indeed, similar trends were shown by [44] in the green alga Ulva rigida. The authors evidenced that the differences in energy losses, and the photosynthetic conditions are more favorable under high nutrients conditions, than low carbon and nitrate. A decrease in chlorophylls and carotenoids was measured in L. spicata individuals in the summertime, which may also be related to low levels of environmental nitrogen as it has been suggested for other macroalgae [45].

In our study, we found that higher internal content of the photoprotectors such as phenolics compounds in summer-season has a relation with photoacclimation patterns. The phenol and antioxidant capacity of this seaweed increased in spring, a period concomitant with high solar irradiance and nutrient in surface waters due to upwelling. L. spicata could accumulate nitrogen during winter and spring as a reservoir for periods of high irradiance and need of photoprotective mechanisms; for instance, as observed in summer in C. tamariscifolia, $[7,9,12]$. The PC, as photoprotective substances, presented a positive 
correlation with antioxidant capacity; this response suggests an increase in the process of energy dissipation and antioxidant control under great solar irradiance. High levels of PC were also detected in C. tamariscifolia in the Mediterranean Sea during high solar irradiance in springtime, which was attributed to increase of PAR and UV radiation [7]. Also considering that the process of acclimation, due to high levels of radiation is dependent on greater non-photochemical quenching, photoinhibition, and the accumulation of UV screening photoprotector $[9,46]$.

In addition, it has been observed that L. spicata displays an increase in PC upon excess solar radiation, evidenced after $48 \mathrm{~h}$ of UV and PAR exposure in the laboratory [5]; similar observations have been made in Macrocystis pyrifera, a cosmopolitan macroalga and a species with a key ecological role [47-49]. Records by [7] in the brown macroalga $C$. tamariscifolia revealed higher total antioxidant capacity during summer (average 10,165 $\mathrm{kJ} \mathrm{m}^{-2}$ PAR, $1051 \mathrm{~kJ} \mathrm{~m}^{-2}$ UVA, and $57.5 \mathrm{~kJ} \mathrm{~m}^{-2} \mathrm{UVB}$ ) compared to daily doses of winter (4000 $\mathrm{kJm}^{-2}$ PAR, $400 \mathrm{~kJ} \mathrm{~m}^{-2} \mathrm{UVA}$, and $\left.15 \mathrm{~kJ} \mathrm{~m}^{-2} \mathrm{UVB}\right)$. In this respect, we found that the highest antioxidant capacity in L. spicata during summer is accordance with PAR and UVA levels of $8000-9000 \mathrm{~kJ} \mathrm{~m}^{-2}$ and 500-600 $\mathrm{kJ} \mathrm{m}^{-2}$, respectively, also accompanied by higher content of PC. This information suggests a proficient photoacclimation strategy to reduce physiological vulnerability. Overall, the photoprotective substances as phenolic compound content was correlated with antioxidant capacity, suggesting an important role of PC in the photoprotection, not only as UV-screening substances, but also as antioxidant compounds [50-52].

General responses in L. spicata demonstrate the development of high photoacclimation adaptations, as evidenced during months with increased solar irradiance. This must be considered when reducing the potential negative effects of solar irradiance on photosynthetic activity. The data showed that L. spicata can produce UV-screening substances and photosynthetic pigments and present high phenotypical plasticity subject to yearly fluctuations in solar irradiance. Thus, the real consequence in these oscillations directly provoke responses inside and they can modulate their photoacclimation or the vulnerability of these sessile species such as other macroalgae [7,12].

\section{Conclusions}

In this study, L. spicata displayed a high photoacclimation capacity, evidenced in increased productivity and dynamic photoinhibition, together with greater UV photoprotections systems, especially during the high irradiance periods of spring and summer. Thus, the phenolics compounds and antioxidant capacity were generally greater throughout these seasons, confirming the photoacclimation strategy to avoid vulnerability in L. spicata.

Supplementary Materials: The following are available online at https://www.mdpi.com/2073 $-4441 / 13 / 1 / 6 / s 1$, Table S1: ANOVA results to address the effect of time on photosynthetic efficiency $\left(\alpha_{\mathrm{ETR}}\right)$, maximal electron transport rate $\left(\mathrm{ETR}_{\mathrm{MAX}}\right)$, saturation of irradiance $\left(\mathrm{Ek}_{\mathrm{ETR}}\right)$, maximal quantum yield $\left(F_{v} / F_{m}\right)$ and maximal non-photochemical quenching (NPQ $\left.\mathrm{NAX}\right)$ in Lessonia spicata. $\left.{ }^{* *}\right) p<0.05$. Table S2: ANOVA results to evaluate the effect of time on chlorophyll $a$, chlorophyll $c$, total carotenoids, phenolic content, and antioxidant capacity of Lessonia spicata. $\left.{ }^{* *}\right) p<0.05$. Table S3: Pearson correlation of the whole data set, considering $\alpha_{\mathrm{ETR}}, \mathrm{ETR}_{\max }, \mathrm{EK}_{\mathrm{ETR}}, F_{v} / F_{m}, \mathrm{NPQ}_{\max }$, Chla, Chlc, total carotenoids (TC), total phenolics compounds (TP), and antioxidant capacity (AA). ** correlation is significant at $p<0.05$.

Author Contributions: A.Z., A.T., D.P., C.N., F.R.-R., F.M.: Investigation, Writing-original draft. C.A.S. and F.L.F.: Investigation, Data curation, Writing—original draft. P.S.M.C.-P.: Investigation, Supervision, Formal analysis, Data curation, Writing-original draft. P.S.M.C.-P.: funding acquisition. All authors have read and agreed to the published version of the manuscript.

Funding: FONDECYT NO. 11180197 granted to P.S.M.C.-P.

Institutional Review Board Statement: Not applicable.

Informed Consent Statement: Not applicable. 
Acknowledgments: This investigation was financed by project FONDECYT NO. 11180197 granted to P.S.M.C.-P.

Conflicts of Interest: The authors declare no conflict of interest.

\section{References}

1. IPCC. The Physical Science Basis. Working Group I Contribution to the Fifth Assessment Report of the Intergovernmental Panel on Climate Change; Cambridge University Press: Cambridge, UK, 2014.

2. Lu, Y.; Wang, H.; Wang, Q.; Zhang, Y.; Yu, Y.; Qian, Y. Global anthropogenic heat emissions from energy consumption, 1965-2100. Clim. Chang. 2017, 145, 459-468. [CrossRef]

3. Bischof, K.; Gómez, I.; Molis, M.; Hanelt, D.; Karsten, U.; Lüder, U.; Roleda, M.Y.; Zacher, K.; Wiencke, C. Ultraviolet radiation shapes seaweed communities. Rev. Environ. Sci. Bio. 2006, 5, 141-166. [CrossRef]

4. Cabrera, S.; Ipiña, A.; Damiani, A.; Cordero, R.R.; Piacentini, R.D. UV index values and trends in Santiago, Chile (33.5 ${ }^{\circ}$ ) based on ground and satellite data. J. Photochem. Photobiol. B Biol. 2012, 115, 73-84. [CrossRef]

5. Gómez, I.; Español, S.; Véliz, K.; Huovinen, P. Spatial distribution of phlorotannins and its relationship with photosynthetic UV tolerance and allocation of storage carbohydrates in blades of the kelp Lessonia spicata. Mar. Biol. 2016, 163, 110. [CrossRef]

6. Rahn, D.A.; Garreaud, R.D. A synoptic climatology of the near-surface wind along the west coast of South America. Int. J. Climatol. 2014, 34, 780-792. [CrossRef]

7. Celis-Plá, P.S.M.; Bouzon, Z.; Hall-Spencer, J.M.; Schmidt, E.; Korbee, N.; Figueroa, F.L. Seasonal biochemical and photophysiological responses in the intertidal macroalga Cystoseira tamariscifolia (Ochrophyta). Mar. Environ. Res. 2016, 115, 89-97. [CrossRef]

8. Celis-Plá, P.S.M.; Rodríguez-Rojas, F.; Méndez, L.; Moenne, F.; Muñoz, P.T.; Lobos, M.G.; Díaz, P.; Sánchez-Lizaso, J.L.; Brown, M.T.; Moenne, A.; et al. MAPK Pathway under Chronic Copper Excess in Green Macroalgae (Chlorophyta): Influence on Metal Exclusion/Extrusion Mechanisms and Photosynthesis. Int. J. Mol. Sci. 2019, 20, 4547. [CrossRef]

9. Figueroa, F.L.; Domínguez-González, B.; Korbee, N. Vulnerability and acclimation to increased UVB in the three intertidal macroalgae of different morpho-functional groups. Mar. Environ. Res. 2014, 97, 30-38. [CrossRef]

10. Sáez, C.A.; Roncarati, F.; Moenne, A.; Moody, A.J.; Brown, M.T. Copper-induced intra-specific oxidative damage and antioxidant responses in strains of the brown alga Ectocarpus siliculosus with different pollution histories. Aquat. Toxicol. 2015, 159, 81-89. [CrossRef]

11. Álvarez-Gómez, F.; Bouzon, Z.; Korbee, N.; Celis-Plá, P.S.M.; Schmidt, E.C.; Figueroa, F.L. Combined effects of UVR and nutrients on cell ultrastructure, photosynthesis, and biochemistry in Gracilariopsis longissima (Gracilariales, Rhodophyta). Algal Res. 2017, 26, 190-202. [CrossRef]

12. Celis-Plá, P.S.M.; Korbee, N.; Gómez-Garreta, A.; Figueroa, F.L. Seasonal photoacclimation patterns in the intertidal macroalga Cystoseira tamariscifolia (Ochrophyta). Sci. Mar. 2014, 78, 377-388. [CrossRef]

13. Sathya, R.; Kanaga, N.; Sankar, P.; Jeeva, S. Antioxidant properties of phlorotannins from brown seaweed Cystoseira trinodis (Forsskal) C. Agardh. Arab. J. Chem. 2017, 10, S2608-S2614. [CrossRef]

14. Ahn, G.N.; Kim, K.N.; Cha, S.H.; Song, C.B.; Lee, J.H.; Heo, M.-S.; Yeo, I.-K.; Lee, N.-H.; Jee, Y.-H.; Kim, J.-S.; et al. Antioxidant activities of phlorotannins purified from Ecklonia cava on free radical scavenging using ESR and $\mathrm{H}_{2} \mathrm{O}_{2}$-mediated DNA damage. Eur. Food. Res. Technol. 2007, 226, 71-79. [CrossRef]

15. Tanniou, A.; Esteban Serrano, L.; Vandanjon, L.; Ibanez, E.; Mendiola, J.A.; Cerantola, S.; Kervarec, N.; La Barre, N.; Marchal, L.; Stiger-Pouvreau, V. Green improved processes to extract bioactive phenolic compounds from brown macroalgae using Sargassum muticum as model. Talanta 2013, 104, 44-52.

16. Wernberg, T.; de Bettignies, T.; Joy, B.A.; Finnegan, P.M. Physiological responses of habitat-forming seaweeds to increasing temperatures. Limnol. Oceanogr. 2016, 61, 2180-2190. [CrossRef]

17. Valdés, F.; Lobos, M.G.; Díaz, P.; Sáez, C.A. Metal assessment and cellular accumulation dynamics in the green macroalga Ulva lactuca. J. Appl. Phycol. 2018, 30, 663-671. [CrossRef]

18. Rodríguez-Rojas, F.; López-Marras, A.; Celis-Plá, P.S.M.; Muñoz, P.; Garcia-Bartolome, E.; Valenzuela, F.; Orrego, R.; Carratala, A.; Sanchez-Lizaso, J.L.; Saez, C.A. Ecophysiological and cellular stress responses in the cosmopolitan brown macroalga Ectocarpus as biomonitoring tools for assessing desalination brine impacts. Desalination 2020, 489, 114527. [CrossRef]

19. González, A.; Beltrán, J.; Hiriart-Bertrand, L.; Flores, V.; de Reviers, B.; Correa, J.A.; Santelices, B. Identification of cryptic species in the Lessonia nigrescens complex (Phaeophyceae, Laminariales). J. Phycol. 2012, 48, 1153-1165. [CrossRef]

20. Quintano, E.; Ganzedo, U.; Díez, I.; Figueroa, F.L.; Gorostiaga, J.M. Solar radiation (PAR and UVR) and water temperature in relation to biochemical performance of Gelidium corneum (Gelidiales, Rhodophyta) in subtidal bottoms off the Basque coast. J. Sea Res. 2013, 83, 47-55. [CrossRef]

21. Quintano, E.; Celis-Plá, P.S.M.; Martínez, B.; Díez, I.; Muguerza, N.; Figueroa, F.L.; Gorostiaga, J.M. Ecophysiological responses of threatened red algae to increased irradiance in an in-situ transplant experiment. Mar. Environ. Res. 2019, 144, 166-177. [CrossRef]

22. Schreiber, U.; Endo, T.; Mi, H.; Asada, K. Quenching analysis of chlorophyll fluorescence by the saturation pulse method: Particular aspects relating to the study of eukaryotic algae and cyanobacteria. Plant. Cell. Physiol. 1995, 36, 873-882. [CrossRef]

23. Figueroa, F.L.; Conde-Álvarez, R.; Gómez, I. Relations between electron transport rates determined by pulse amplitude modulated chlorophyll fluorescence and oxygen evolution in macroalgae under different light conditions. Photosynth. Res. 2003, 75, 259-275. [CrossRef] [PubMed] 
24. Eilers, P.H.C.; Peeters, J.C.H. A model for the relationship between light intensity and the rate of photosynthesis in phytoplankton. Ecol. Model. 1988, 42, 199-215. [CrossRef]

25. Bilger, W.; Björkman, O. Role of the xanthophyll cycle in photoprotection elucidated by measurements of light-induced absorbance changes, fluorescence, and photosynthesis in leaves of Hedera canariensis. Photosynth. Res. 1990, 25, 173-185. [CrossRef]

26. Ritchie, R.J. Fitting light saturation curves measured using modulated fluorometry. Photosynth. Res. 2008a, 96, 201-215. [CrossRef]

27. Kramer, D.M.; Johson, G.; Kiirats, O.; Edwards, G.E. New fluorescence parameters for the determination of QA redox state and excitation energy fluxes. Photosynth. Res. 2004, 79, 209-218. [CrossRef]

28. Hendrickson, L.; Furnbank, R.T.; Chow, W.S. A simple alternative approach to assessing the fate of absorbed light energy using chlorophyll fluorescence. Photosynth. Res. 2004, 82, 73-81. [CrossRef]

29. Ritchie, R.J. Universal chlorophyll equations for estimating chlorophylls a, b, c and d and total chlorophylls in natural assemblages of photosynthetic organisms using acetone, methanol, or ethanol solvents. Photosynthetica 2008b, 46, 115-126. [CrossRef]

30. Parsons, T.R.; Strickland, J.D.H. Discusson of spectrophometric determination of marine-plant pigments, with revised equations for ascertaining chlorophyll-a and carotenois. J. Mar. Res. 1963, 21, 105-156.

31. Folin, O.; Ciocalteu, V. On tyrosine and tryptophane determinations in proteins. J. Boil. Chem. 1927, 73, 627-650.

32. Blois, M.S. Antioxidant determinations by the use of a stable free radical. Nature 1958, 181, 1199-1200. [CrossRef]

33. Underwood, T. Experiments in Ecology. Their Logical Design and Interpretation Using Analysis of Variance; Cambridge University Press: Cambridge, UK, 1997.

34. Anderson, M.J.; Gorley, R.N.; Clarke, K.R. PERMANOVA+ for PRIMER: Guide to Software and Statistical Methods; PRIMER-E: Plymouth, UK, 2008.

35. Ogawa, T.; Sonoike, K. Effects of bleaching by nitrogen deficiency on the quantum yield of photosystem II in Synechocystis sp. PCC 6803 revealed by Chl fluorescence measurements. Plant Cell Physiol. 2016, 57, 558-567. [CrossRef]

36. Maxwell, K.; Johnson, G.N. Chlorophyll fluorescence-a practical guide. J. Exp. Bot. 2000, 51, 659-668. [CrossRef]

37. Gómez, I.; López-Figueroa, F.; Ulloa, N.; Morales, V.; Lovengreen, C.; Huovinen, P.; Hess, S. Patterns of photosyntheisis in 18 species of intertidal macroalgae from southern Chile. Mar. Ecol. Prog. Ser. 2004, 270, 103-116. [CrossRef]

38. Hanelt, D. Photoinhibition of photosynthesis in marine macroalgae. Sci. Mar. 1996, 60, 243-248.

39. Celis-Plá, P.S.M.; Martínez, B.; Korbee, N.; Hall-Spencer, J.M.; Figueroa, F.L. Ecophysiological responses to elevated CO 2 and temperature in Cystoseira tamariscifolia (Phaeophyceae). Clim. Chang. 2017, 142, 67-81. [CrossRef]

40. Hoogenboom, M.O.; Anthony, K.R.N.; Connolly, S.R. Energy cost of photinhibtion in corals. Mar. Ecol. Prog. Ser. 2006, 313, 1-12. [CrossRef]

41. Raven, J.A. The cost of photoinhibition. Physiol. Plant. 2011, 142, 87-104. [CrossRef]

42. Pavia, H.; Toth, G.B. Inducible chemical resistance to herbivory in the brown seaweed Ascophyllum nodosum. Ecology 2000, 81, 3212-3225. [CrossRef]

43. Cabello-Pasini, A.; Macías-Carranza, V.; Abdala, R.; Korbee, N.; Figueroa, F.L. Effect of nitrate concentration and UVR on photosynthesis, respiration, nitrate reductase activity, and phenolic compounds in Ulva rigida (Chlorophyta). J. Appl. Phycol. 2011, 23, 363-369. [CrossRef]

44. Figueroa, F.L.; Bonomi-Barufi, J.; Celis-Plá, P.S.M.; Nitschke, U.; Arenas, F.; Connan, S.; Abreu, M.H.; Malta, E.-J.; Conde-Álvarez, R.; Chow, F.; et al. Short-term effects of increased $\mathrm{CO}_{2}$, nitrate and temperature on photosynthetic activity in Ulva rigida (Chlorophyta) estimated by different pulse amplitude modulated fluorometers and oxygen evolution. J. Exp. Bot. 2020, eraa473. [CrossRef] [PubMed]

45. Parjikolaei, B.R.; Kloster, L.; Bruhn, A.; Rasmussen, M.B.; Fretté, X.C.; Christensen, K.V. Effect of light quality and nitrogen availability on the biomass production and pigment content of Palmaria palmata (Rhodophyta). Chem. Eng. Trans. 2013, 32, 967-972.

46. Abdala-Díaz, R.T.; Cabello-Pasini, A.; Pérez-Rodríguez, E.; Conde-Álvarez, R.M.; Figueroa, F.L. Daily and seasonal variations of optimum quantum yield and phenolic compounds in Cystoseira tamariscifolia (Phaeophyta). Mar. Biol. 2006, 148, 459-465. [CrossRef]

47. Buschmann, A.H.; Pereda, S.V.; Varela, D.A.; Rodríguez-Maulén, J.; López, A.; González-Carvajal, L.; Schilling, M.; HenríquezTejo, E.A.; Hernández-González, M.C. Ecophysiological plasticity of annual populations of giant kelp (Macrocystis pyrifera) in a seasonally variable coastal Environment in the Northern Patagonian Inner Seas of Southern Chile. J. Appl. Phycol. 2014, 26, 837-847. [CrossRef]

48. Varela, D.A.; Henriquez, L.A.; Fernández, P.; Leal, P.; Hernández-González, M.C.; Figueroa, F.L.; Buschmann, A.H. Photosynthesis and nitrogen uptake of the giant kelp Macrocystis pyrifera grown close to salmon farms. Mar. Environ. Res. 2018, 135, 93-102. [CrossRef]

49. Palacios, M.; Osman, D.; Ramirez, J.; Huovinen, P.; Gómez, I. Photobiology of the giant kelp Macrocystis pyrifera in the landterminating glacier fjord Yendegaia (Tierra del Fuego): A look into the future? Sci. Total Environ. 2020, 751, 141810. [CrossRef]

50. Stahl, W.; Sies, H. Carotenoids and flavonoids contribute to nutritional protection against skin damage from sunlight. Mol. Biotechnol. 2007, 37, 26-30. [CrossRef]

51. Stengel, D.B.; Connan, S.; Popper, Z.A. Algal chemiodiversity and bioactivity: Sources of natural variability and implications for commercial application. Biotechnol. Adv. 2011, 29, 483-501. [CrossRef]

52. Hanelt, D.; Figueroa, F.L. Physiological and photomorphogenic effects of light of marine macrophytes. In Seaweed Biology Ecological Studies; Wienke, C., Bischof, K., Eds.; Springer: Berlin/Heidelberg, Germany, 2012; pp. 3-23. 